University of Miami Law School University of Miami School of Law Institutional Repository

1977

The Third United Nations Conference on the Law of the Sea: the 1976 New York Sessions

Bernard Oxman

Follow this and additional works at: https://repository.law.miami.edu/fac_articles Part of the Law of the Sea Commons 


\title{
THE THIRD UNITED NATIONS CONFERENCE \\ ON THE LAW OF THE SEA: THE 1976 NEW YORK SESSIONS *
}

\author{
By Bernard H. Oxman *
}

The law of the sea has changed, for good or for ill. The Revised Single Negotiating Text " (hereinafter RSNT) issued in the spring of 1976 may prove to be the single most important document regarding the law of the sea since the 1958 Geneva Conventions in terms of its influence on state practice, whether by way of an ultimate treaty or otherwise. Important differences will exist regarding the extent to which portions of the text are declaratory of emerging customary international law and regarding the extent to which the text must be changed to be acceptable as a universal treaty or as customary law. Indeed, difficult questions of implementation of its principles in bilateral and other arrangements are already arising. Positions taken at multilateral conferences may differ from the positions taken in other contexts. But the text will not be ignored.

Should the Conference ultimately be unable to reach agreement on a treaty, this circumstance will be one of the great ironies in the history of codification and progressive development of international law. It is readily apparent to the participants that this Conference has already achieved agreement in principle on issues that could not be resolved at the earlier Hague and Geneva Conferences and on fundamental legal questions of environmental protection that were not even faced at the earlier conferences. Some of these issues have caused serious difficulties in international relations for some time. Yet the chances for a widely acceptable treaty are in jeopardy in large measure because of fundamental political disagreement over mining of deep seabed manganese nodules-an activity that has yet to begin; that by the end of the century may account for little more than a dozen mine sites out of an area that is nearly half the size of the planet; and that is likely to have less immediate effect on the basic interests of most states than other activities dealt with in the text. In economic terms alone, the irony is apparent if one considers that the Con-

\footnotetext{
- This article is a sequel to Stevenson \& Oxman, The Preparations for the Law of the Sea Conference, 68 AJIL 1 (1974); The Third United Nations Conference on the Law of the Sea: the 1974 Caracas Session, 69 AJIL 1 (1975); and The Third United Nations Conference on the Law of the Sea: the 1975 Geneva Session, 69 AJIL 763 (1975).

- U.S. Representative and Deputy Chief of Delegation, 1976 New York Sessions of the Law of the Sea Conference; Assistant Legal Adviser for Oceans, Environment and Scientific Affairs, U.S. Department of State. The views expressed herein are those of the author and do not necessarily represent the views of the Department of State or the U.S. Government.

${ }^{x}$ Revised Single Negotiating Text, U.N. Doc. A/Conf.62/WP.8/Rev.1, May 6, 1976 (hereinafter RSNT).
} 
ference has reached virtual agreement on the disposition of all the living resources of the sea and virtually all of the hydrocarbon resources of the sea-major and growing parts of the world's supply of animal protein, energy, and petrochemicals.

The third substantive session of the Conference was held in New York from March 15 to May 7, 1976. Following the same procedure used for the single negotiating text (SNT), ${ }^{2}$ the Chairmen of the three Main Committees prepared revised single negotiating texts (RSNT) ${ }^{3}$ and the President prepared a single negotiating text on settlement of disputes. ${ }^{4}$ Significant changes were made in the Committee I text on deep seabeds and in the Committee III texts on scientific research and protection of the marine environment. The Committee II texts, which commanded very broad support in general, were refined in some respects.

The fourth substantive session was held in New York from August 2 to September 10, 1976. The Chairmen of the Main Committees issued detailed reports, ${ }^{5}$ but no newly revised texts. The President issued a revised text on dispute settlement after the session, ${ }^{6}$ thus bringing the text on that subject to the same stage as the others. The Conference recommended that another session be held in New York commencing in May 1977. It favored devoting the first three weeks of that session principally to Committee I problems, and subsequent completion of a consolidated text of the entire draft treaty by the President of the Conference. Discussion was deferred on the final articles (entry into force, etc.) and on the report of the Secretary General on this matter. ${ }^{7}$

Many delegations insisted that the next session of the Conference must be decisive. Representatives of some of the developing countries in particular noted the limited manpower and resources at their disposal for participation in a variety of international negotiations. This consideration raises interesting questions of procedure, not only regarding the possibilities for agreement, but also as to the weight to be accorded to a text both in the negotiations and otherwise.

The Conference normally functions by consensus. It has not voted on or approved a single article. The consensus procedure is considered necessary to achieve widespread agreement on what can truly be regarded as universal law. The inherent significance of the RSNT depends on the degree to which the Chairmen have correctly perceived the basis for

2 Informal Single Negotiating Text, UN Doc. A/Conf.62/WP.8, May 7, 1975; reprinted at 14 ILM 682 (1975). See also Stevenson \& Oxman, The Third United Nations Conference on the Law of the Sea: the 1975 Geneva Session, 69 AJIL 763-64 (1975).

3 Note I, supra.

4 UN Doc. A/Conf.62/WP.9/Rev.1, May 6, 1976. 15 ILM 61 (1976).

5 UN Doc. A/Conf.62/L.16 (Committee I), L.17 (Committee II), L.18 (Committee III), Sept. 16, 1976.

${ }^{6}$ UN Doc. A/Conf.62/WP.9/Rev.2, Nov. 23, 1976.

7 UN Doc. A/Conf.62/L.13, July 26, 1976. 
agreement and balanced the conflicting interests at play. ${ }^{8}$ Its ultimate significance depends on the degree to which it is respected either in the process of completing a treaty or in the absence of a widely ratified treaty. To the extent that the Chairmen's perceptions are correct, it is a fair guess that fundamental changes either at the Conference or in state practice may doom the prospects for any true international law of the sea, conventional or customary, for a generation or more.

This is not the place to predict whether a concert of maritime powers, or any other group, could have its way without a treaty, on the speculative assumption that the relevant groups could unite in practice. The likely result would probably depend on the issue. But a contest for power does not make law simply because the contestants pronounce legal conclusions to justify their actions, or because their apologists really do believe that they are correct. In functional terms, law will only emerge once there is a clear victory, or the contest is resolved by agreement, formal or informal. The significant question facing states in deciding on the benefits and costs of a treaty has less to do with the oceans or the specific rules of law than with their perception of the kind of world in which they want to live and the role of law in such a world.

The basic structure of the law of the sea in the RSNT is essentially the same as in the original single negotiating text. ${ }^{9}$ Two basic groups of issues

"The Introductory Note to the RSNT by the President of the Conference concludes:

The President presents these texts to the Conference as a procedural device to carry forward the process of negotiation in the expectation and the hope that the future negotiations will help towards the attainment of general agreement in keeping with the letter and spirit of the "Gentleman's Agreement" regarding the conclusion of a Treaty or a Convention by consensus.

The text of the "Gentleman's Agreement" can be found in the Appendix to the Rules of Procedure of the Conference, UN Doc. A/Conf.62/30/Rev.2.

"The following ten points were elaborated in Stevenson \& Oxman, supra note 2, at 764-65:

(1) a maximum 12-mile limit for the territorial sea, over which the coastal state will have sovereignty, subject to a right of innocent passage, with some elaboration of the rules of innocent passage;

(2) unimpeded passage of straits used for international navigation for all vessels and aircraft;

(3) a 200-mile economic zone in which the coastal state exercises sovereign rights over the exploration, exploitation, conservation, and management of living and nonliving resources and in which all states continue to enjoy freedoms, in particular of navigation and overflight and other uses related to navigation and communication; coastal state sovereign rights over the exploration and exploitation of the resources of the seabed and subsoil of the continental margin where it extends beyond 200 miles, coupled with a duty to contribute some international payments in respect of mineral production in the area of the margin beyond 200 miles;

(4) comprehensive coastal state control of all drilling and of all economic installations in the economic zone;

(5) some adjustment and modernization of the regime of the high seas, for example the recognition of the special interest and responsibility of the state of origin for anadromous species of fish and new rules with respect to control of unauthorized broadcasting and cooperation in the suppression of illicit traffic in narcotics;

(6) an elaboration of a concept of island nations as archipelagic states which includes a precise definition of a new category of archipelagic waters and a regime of unimpeded passage through archipelagic sealanes and air routes that traverse the archipelago; 
are outstanding, although other problems remain. The first concerns the work of Committee I-the international regime and machinery regarding the exploitation of deep seabed minerals. The second concerns a number of unresolved issues regarding the 200-mile economic zone-the juridical status of the zone, the access of landlocked and geographically disadvantaged states to fisheries in the zones of their neighbors, related problems of the continental margin where it extends beyond 200-miles, scientific research in the zone, delimitation between opposite and adjacent states, and the application of third-party procedures to disputes regarding the zone.

By its very nature, the work on the international regime for the deep seabeds is not as likely to have a direct impact on the development of customary law as much of the rest of the work of the Conference. The centerpiece of that regime would be a new international organization that could only be created by agreement. Nevertheless, the fact that this part of the negotiation constitutes the greatest obstacle to a treaty has signifcance for the general development of international law by global multilateral negotiations. It is open to question whether the "codification and progressive development" of international law ever fell victim to big power rivalries to quite the extent that this process has been hampered by the newer North-South differences. What must be noted is not merely that certain differences between industrialized and developing countries may need to be addressed in the course of resolving the relevant legal problems, but that the negotiations have been seized as an occasion to press these differences in a display of group unity. In a sense, the law is being held hostage.

On the other hand, work on the economic zone is likely to have great impact on unilateral state practice. This is already becoming clear. The significant point is not merely that coastal states are making claims based in large measure on the texts, but that these claims (like the texts) seek to accommodate the interests of others, and that other states are accommodating to the claims. It is impossible to say that this would not have occurred in the absence of the negotiations, but the negotiation of common principles certainly facilitated the process. Considering the vast areas and major interests involved, the importance of paving the way for peaceful change cannot be dismissed lightly. The key question of course is whether the accommodations will last or whether coastal states in particular will seek more in the future.

(7) international standards to prevent and control marine pollution, and limited coastal state enforcement rights with respect to vessel-source pollution;

(8) specified coastal state and flag state rights and duties with respect to scientific research in the economic zone and on the continental shelf, and general provisions regarding international cooperation in marine scientific research and transfer of marine technology;

(9) an international regime and machinery to deal with the exploration and exploitation of seabed resources beyond the limits of national jurisdiction (that is, beyond the economic zone or continental margin);

(10) a system for peaceful third-party settlement of disputes regarding the interpretation or application of the Convention which have not been resolved by negotiation or other agreed procedures. 
A detailed examination of these two sets of issues is potentially helpful in understanding the stage reached in the negotiations and in charting future developments in the law of the sea with or without an early and comprehensive treaty. It can also be helpful in addressing a major dilemma that may face those concerned with the peaceful adaptation of international law to changed circumstances: Do the distortions that may result from numerical strength in multilateral fora outweigh the distortions that may result from the ability and willingness to apply strength in specific circumstances affecting the development of customary law? The costs of the former course are usually more obvious; are they now also greater in substance?

\section{The Deep Seabeds}

It is customary to analyze the deep seabeds problem in terms of the contrasting interests of industrialized and developing countries. This is a tribute to the skill of those states that see their interests best served by defining international negotiations in these terms. In fact, a number of divergent interests are involved. A major difference between the negotiations on the economic zone and the negotiations on the deep seabeds is that, in the former instance, these divergent interests surfaced in the Conference as a whole, resulting in the formation of a variety of formal and informal interest groups cutting across regional and political lines. In the deep seabeds negotiation, every important article is becoming the subject of an official "Group of 77 " position, ${ }^{10}$ despite the existence of substantial divergences of interest within that group.

The major direct economic interests regarding the deep seabeds can be classified in different ways. The following are some of them:

(1) Consumption of metals produced from the deep seabeds. If one disregards nationality, the overwhelming majority of all people in the world have at least indirect consumer interests in nickel, copper, manganese, and cobalt. Even on a state-by-state basis, the majority of states are net importers of these metals, directly or in finished products. Put simply, the consumer interest is in the avoidance of underproduction and in the minimization of prices. The consumer is concerned both with the efficiency of production and with the security of supply. The identity of the producer is in practice-if not necessarily in theory-relevant to both.

(2) Internal national production of the metals produced from the deep seabeds. Many people currently earn their livelihood, directly or indi-

21" The "Group of 77" now includes over 100 "developing countries" embracing wide variations in wealth, income, and agricultural industrial development. In his report, the Chairman of Committee I states:

I am convinced that we shall spend decades in fruitless dialogue if we continue to accept that the interests at this Conference may naively be classified into two: those of the developed versus those of the developing countries. Neither group is without a diversity of concrete interests, given the factor of uneven development within.

Supra note 5, at 10 (English text). 
rectly, from the mining of nickel, copper, cobalt, and manganese. Exports of these minerals contribute to the foreign exchange earnings of some states, although the number of states is small, and the major exporters include some highly industrialized states. Put simply, producers would like to avoid overproduction (particularly by their competitors) and to maximize prices. While the term "land-based" producers is used for this category, and the manganese nodule deposits of great interest are generally far out to sea, it is possible that some states, particularly those bordering the Pacific, may see themselves as becoming internal producers of manganese nodules found within their economic zones (or continental shelves if a distance criterion is used as part of the definition).

(3) Immediate deep seabed production. A number of enterprises currently expect to be deep seabed producers within the next decade or so. They are concentrated in a few industrialized states. However, the investments involved are large, on the order of $\$ 500$ million per mine site. Opportunity for investment and growth, stability of expectations, a sufficient rate of return, and minimum outside interference are sought.

(4) Potential deep seabed production. The number of states that have reasonable expectations of being involved in at least some aspects of deep seabed mining (perhaps by the turn of the century) is by no means small, and by no means limited to currently highly industrialized states. The group clearly can include developing countries that are now rapidly industrializing, or that will have significant surplus capital at their disposal, or that enjoy good conditions for attracting processing plants from the point of view of mine site or market proximity, investment climate, and environmental restraints. While this group may share the interests of the immediate producers, it also wishes to ensure conditions favorable to future new entrants into the industry.

(5) Public economic return. It is customary in most societies to obtain some direct economic return for the extraction of public mineral reserves, such as a royalty or a share of profits. Most countries desire to impose and share in an economic return on deep seabed mineral extraction, despite the fact that it is not clear that global manganese nodule reserves will in fact be "depleted" in a strict sense. The debate over the ownership of the deep seabeds does not have an impact on this issue. The principle of generating revenues for the international community as a whole, primarily for the benefit of developing countries, is not disputed as an element of an ultimate treaty. However, the nature of the return, perhaps more so than the amount, is a major problem.

In and of themselves, there is nothing unique or insurmountable about these divergences of interest. Many nations must deal with them internally all the time. The problems inherent in arriving at a settlement on the economic zone were certainly more pressing, and arguably far more complex. It is the author's view that the reason that more progress has not been made is that sufficient immediate interests are not perceived by a sufficient number of states. This would be consistent with a number 
of other explanations, such as ideology, dissatisfaction by some with the Committee II text, and lack of "political will."

In this situation, "broader" interests come to the fore in a highly conceptualized manner. The willingness to contest group ideology on the ground of achieving beneficial practical results is reduced. The urge to build a model relevant to unspecified present or future interests of little relevance to the deep seabeds becomes irresistible. Admittedly, uncertainty as to what lies below the surface of the deep seabeds adds to this, but it might be noted that this uncertainty did not preclude the emergence of a consensus that the resource jurisdiction of coastal states could go as far as, but not farther than, a 200-mile limit or, under the RSNT, the edge of the continental margin.

Thus, for many countries the Committee I negotiations are not about the deep seabeds or the minerals involved. They are about the future structure of the United Nations, totally unrelated commodities, and the role of multinational corporations in the development of national land and offshore resources. This perception leads some to argue that a deep seabeds regime cannot be achieved until there is a broader North-South settlement. But if one believes that "settlement" is a dynamic process of many components rather than an event, then this is no answer.

The idea of the "Enterprise" deserves consideration in this regard. The Enterprise is proposed as the organ of the Seabed Authority that actually engages in mining operations by itself or, if it wishes, through contractors. The early arguments of industrial states against the Enterprise, and the current arguments of its proponents for special favorable treatment as against both state and private mining operations, reveal a curious consensus: the Enterprise is not expected to be as efficient as other operators. Who benefits from the inevitable reduction in public economic return and higher costs? While the Enterprise is frequently seen as a "concession" from rich to poor, it is in fact a "concession" whereby, in place of the revenues developing countries would otherwise receive directly, a collective decision has been taken to go into the mining business with those revenues.

The stated objective is "control." This emphasis on abstraction hides three underlying objectives of far broader scope: first, greater "control" of international organizations by developing countries; second, greater "control" of raw material markets by producers; and third, greater "control" of national resource development projects by the state. The deep seabeds negotiation is seen as a "precedent." This is not to suggest that the majority of developing countries insist on these three points as a sine qua non for a treaty, but rather that they do not resist the few who wish to use the negotiation as a test skirmish on the issues or to demonstrate their leadership potential. The basic interests in the deep seabeds still can be accommodated if the negotiations are brought back to those interests from their current level of abstraction.

The idea behind the system in the RSNT is a relatively simple one, variously referred to as the "parallel system" or the "banking system." The 
parallel system of exploitation is one under which both the Enterprise and state or private companies exploit the deep seabeds. ${ }^{11}$ Under the "banking system" approach to a parallel system, every applicant for a mine site (a "contract") would have to satisfy certain basic conditions. ${ }^{12}$ One of these would be the simultaneous submission of two sites of equivalent value, one of which would be reserved for development by the Enterprise or a qualified developing country. ${ }^{13}$ Various rules regarding mining would be specified in the treaty, ${ }^{14}$ while others would be elaborated by the Council of the Seabed Authority on the basis of treaty criteria, subject to veto by one-fourth of the Contracting Parties. ${ }^{15}$ Disputes would be submitted to a special tribunal of the Seabed Authority. ${ }^{10}$ The system includes a twenty year overall limit on production based on a cumulative six percent growth segment of the nickel market which may be extended for five years. Among other things, this reassures developing country producers of metals found in manganese nodules; provides for implementing applicable commodity arrangements with respect to deep seabed mining; and contains provision for adjustment assistance to developing country producers which are adversely affected. ${ }^{17}$

Secretary of State Kissinger indicated at the spring session of the Conference that as part of a parallel system that includes assured access for states and their nationals, the United States would be willing to help the Enterprise get into business simultaneously or virtually simultaneously with other miners and would support a review of the system of exploitation after about twenty-five years. ${ }^{18}$ The United States also circulated an informal text on composition and voting of the Council which would give special protection to a variety of interests, particularly consumers and landbased producers. ${ }^{19}$

11 RSNT, Part I, Art. 22.

12 Id. Annex I. See especially paras. 4-12.

$13 \mathrm{Id}$. Annex I, para. 8(d).

I4 Generally id. Annex I, other than paras. 7 \& 12.

${ }^{15}$ Generally id., Arts. 12, 13, 16, 22, 28(2)(xii); Annex I, paras. 7 \& 12; Special Appendix.

16 Id. Arts. 33-40; Annex III.

17 Id. Art. 9; Annex I; paras. 8(a) (iv), 21.

${ }^{18}$ See 74 Dept. State Burl. 539 (1976). See also report of the Chairman of Committee I, supra note 5, at 8, 9 (English text).

19 Text of the U.S. informal text of Sept. 7, 1976:

Article 27

The Council

Composition

1. The Council shall consist of 36 members of the Authority elected by the Assembly, the election to take place in the following order:

(a) The six industrialized States which have made the greatest contributions to the understanding of, the exploration for and the exploitation of, the resources of the Area as demonstrated by substantial investments or advanced technology in relation to the resources of the Area, including at least one Eastern European State;

(b) Six States from among the developing countries, including at least two from among the least developed countries;

(c) The six States which are the largest producers of the categories of minerals to be derived from the Area; 
Thoughtful questions have been raised regarding the degree of detail in Part I of the RSNT. Much of it is of course analogous to the detail in national mining laws and regulations. But a more basic consideration is in-

(d) The six States which are the largest consumers of the categories of minerals to be derived from the Area;

(e) Twelve States elected according to the principle of equitable geographic distribution, to include at least two from each of the following regions: Africa, Asia, Latin America, Eastern Europe, and Western Europe \& Others.

2. At least one-fourth of the members of the Council shall be landlocked and geographically disadvantaged States.

3. In electing the Council, the Assembly shall ensure that the members of the Council, taken as a whole, account for one-half of the value of the production and of the consumption of the categories of minerals to be derived from the Area accounted for by the members of the Authority.

4. A State Party which is qualified for election to more than one of the categories specified in paragraph 1 above shall select the category to which it chooses to be elected and, in the event it is not elected to this category, may select to be a candidate for another category for which it is qualified.

5. Members shall be eligible for reelection.

6. Elections shall take place at regular sessions of the Assembly, and each member of the Council shall be elected for a term of four years.

7. The Council shall function at the seat of the Authority and shall meet in continuous session, unless it decides otherwise.

Voting

8. Each member of the Council shall have one vote.

9. Decisions on questions of procedure shall be made by a simple majority of the members present and voting.

10. Except as provided in paragraph 11 of this Article, all decisions on questions of substance shall be made by a three-fourths majority of the members of the Counil, provided that such majority represents more than one-half of the total value of the production, as well as more than one-half of the total value of the consumption, of the categories of minerals to be derived from the Area accounted for by the memhers of the Authority. If any member of the Council objects to a ruling by the President on whether a question is one of substance or not, that question shall be treated as a question of substance unless the Council by the majority specified in this paragraph decides otherwise.

11. All decisions related to the exercise of the Council's powers and functions concerning the adoption of necessary and appropriate measures in accordance with paragraph 4 of Article 9, the budget of the Authority and the assessment of contributions of States Parties and matters under Articles _ shall be made by a threefourths majority of the members of the Council, provided that such majority represents at least three-fourths of the total value of the production, as well as threefourths of the total value of the consumption, of the categories of minerals to be derived from the Area accounted for by the members of the Authority. If any member of the Council objects to a ruling by the President on whether a question falls under this paragraph or not, that question shall be treated as falling under this paragraph unless the Council by the majority specified in this paragraph decides otherwise.

12. Before any matter of substance is put to a vote, a determination that efforts have been made to reach general agreement shall be made by the majority specified in paragraph 10.

Participation by All Members of the Authority

13. In order to ensure the widest possible participation by all members of the Authority in the decisions of the Council, each State Party shall have the right to assign the value of the production and of the consumption of the categories of minerals to be derived from the Area for which it accounts to another State Party for the purpose of composing the Council or to a member of the Council for the purpose of voting.

14. The Council shall establish a procedure whereby a member of the Authority not represented on the Council may send a representative to attend a meeting of the Council when a request is made by such member, provided that a matter particularly affecting it is under consideration. Such a representative shall be entitled to participate in the deliberations but not to vote. 
volved. If one assumes that a certain condition on mining is or may be necessary, there are three basic choices for establishing the condition that involve striking a balance between predictability and flexibility-(i) to specify the condition objectively in the treaty; (ii) to defer to the Authority and to give specific guidance on what type of condition the Authority might impose under what circumstances; or (iii) to leave broad discretion to achieve a general objective. All three are in fact used in the RSNT. The problem is that if the matter itself is contentious, deferral of the issue vastly increases the uncertainty, places even greater burdens on the already difficult problem of decisionmaking procedures, and in essence asks a state in advance to accept the possibility of a result contrary to its interests.

The debate surrounding such phrases as "guaranteed access" or "controlled access" in fact involves this balance of predictability and flexibility. But perhaps equally importantly, it involves a question of procedural fairness and nondiscrimination. Policy decisions should be equally applicable to all prospective miners and should be taken in sufficient time to allow adequate planning by all concerned. Such decisions should be made in the treaty, the annexes, and in the Authority's rules and regulations adopted thereunder, not in the context of a particular application to mine. The proponents of guaranteed access are not arguing for uncontrolled access; they are arguing that applications that comply with existing objective requirements, including the production limitations, should be granted. A political decision is not involved in the granting or denial of a contract. While some questions of interpretation may inevitably arise, that act is essentially ministerial. The political decisions are to be incorporated in the treaty, the annexes, and the rules and regulations adopted thereunder that govern the question of the requirements with which the application must comply.

By contrast, a system of "negotiated access," such as some states employ on land, necessarily implies discretion as to the issues being negotiated on the part of the Authority's "negotiator," and in all probability, differences in treatment of different applicants as well. To the extent that basic economic interests are at stake, such a system amounts to a decision to provide for wide discretion without even the procedural guarantee that such discretion will be exercised in a generally applicable and nondiscriminatory way.

One of the interesting aspects of this part of the RSNT is its approach to the question of the exclusive right to use an area. First, as with the economic zone, the right to use is exclusive only for certain purposes-in this case resource purposes. ${ }^{20}$ Second, in sharp contrast to the continental shelf concept or claims by states to land areas, the exclusive right to use is temporary and does not include a right not to use. Following the pattern in national mining laws, a mining contract would have a specified term and would be subject to stated performance requirements. ${ }^{21}$ The main

${ }^{20}$ RSNT, Part I, Art. 1(ii); Annex I, paras. 6(c), 11.

${ }^{21} I d$. Annex I, para. $12(\mathrm{~b})(2),(3),(7)$. 
purpose of course is to prevent speculative claims. Even the Enterprise must decide whether it wishes to use a reserved mine site. ${ }^{22}$ The key factor here is that rights are not ascribed to states (or their nationals) on the basis of effective occupation, as on land, or ipso facto, as on the continental shelf and, presumably, the economic zone. ${ }^{23}$ The very size of the area granted is tied to production. ${ }^{* *}$ Locke might well have been comfortable with this system of "property." 25 Faced with the problem of seabed mining, Grotius might have been as well.

In terms of the development of customary law, the heart of this novel and perplexing problem is precisely the question of linking rights and use. Even the RSNT does not specify the size, duration, and performance requirements per se, but merely the criteria to be applied. Yet, if any one of these three limitations were to be omitted in form or effect from a law which still permits exclusive rights, a permanent (or renewable) property interest could potentially derive from a claim alone.

In this connection, it is interesting to note that the RSNT places no such limitations on prospecting, as prospecting "may be carried out by prospectors in the same area simultaneously," and confers no "preferential, proprietory, or exclusive rights on the prospector with respect to the resources or minerals." 26

The question of "access" to seabed mine sites has a negative as well as positive aspect. Without effective protection from preemptive claims by others, a positive right of access can quickly become a legal fiction. The contest can as easily take place in national courts as at sea.

Without some type of agreement, however limited in scope and participation, how does one establish that a period of $X$ years is permissible for commencement of commercial production, that $Y$ dollars is a permissible minimum level of investment, or that $Z$ tons is a permissible minimum level of production? In whose opinion do $X+1, Y-1$, and $Z-I$ all violate "customary international law"? What is the practical situation of a company that believes, with its government, in the $X, Y$, and $Z$ figures if it "poaches" on a "preemptive" claim recognized by a foreign state when the company has personnel or assets subject to the jurisdiction of that foreign state? What if there are "Alag of convenience" enforcement prob-

$\because 2$ Id. Annex I, para. 8(d) (ii).

is See id., Part II, Arts. 44, 65; Convention on the Continental Shelf, Art. 2, 15 UST 471, TIAS No. 5578, 499 UNTS 311, 52 AJLL 585 (1958).

* RSNT, Part I, Annex I, para. 12(b) ( I).

${ }^{2 \pi}$ An analogy can be made between the deep seabeds requirements and the duty of full utilization with respect to fisheries in the economic zone (RSNT, Part II, Art. 51), particularly since the concept of full utilization was for some delegations central to the acceptability of the economic zone concept as a whole. However, the duration of the coastal state economic zone rights is not temporary, and the size of the area granted is not tied to production. On the other hand, the duty of full utilization in effect qualifies the exclusive right to use all of the fisheries if there is a surplus. The coastal state may control and regulate foreign access to the surplus, but may not arbitrarily prohibit it.

$\because$ RSNT, Part I, Annex I, para. 3. 
lems regarding foreign claims? Assuming cases could be brought before the International Court of Justice (which is questionable), will the Court (with little direct precedent) conclude that an exclusive property interest is permissible and that continuous use of an area of a specific size is a condition of the property interest? If so, will it not be forced in effect to impose its view of the correct figures?

There is a natural tendency to view the private and public aspects of this problem separately. In fact, both the consumer and a responsible miner can be prejudiced by preemptive claims stimulated by private speculators or stimulated by geopolitical interests of states. And if speculation is allowed any success, others will be impelled to join the process quickly. The weight to be accorded this consideration in shaping possible alternatives to a global treaty is related not only to the probability of its occurrence, but also to the magnitude of the effect if it does occur.

At the least, it should be recognized that the problem is substantive, not cosmetic. A right of one man corresponds to the duty of another. Property can be expressed either as a right of use erga omnes or as a duty of others to refrain from such use. Expressing it as a duty to have reasonable regard for the user changes nothing of substance if the object of that reasonable regard is not merely accommodation of physical operations-usually safety-but protection of a priority interest in future use of the area itself.

Since analogies may be made to safety zones around artificial installations, it is important to note that under the RSNT the safety zones are of very limited size, must be "designed to ensure that they are reasonably related to the nature and function of the . . . installations," and entail jurisdiction of the coastal state only to "take appropriate measures to ensure the safety both of navigation and of the ... installation." ${ }^{27}$ The underlying accommodation is one of physical operations.

The debate over seabed mining abounds in analogies, sometimes regarded as precedents. The problem is that analogies can be found to support virtually any desired result, and many can be distinguished just as easily. The debate also abounds in appeals for a standard of reasonableness, with the implication that an entire body of conduct can be derived from unilateral application of a rule of reason-applied by which philosopher-king? The author is unaware of any rule that "states may make reasonable use of the high seas." The high seas are open to all states. States may exercise the freedoms of the high seas, some express, some "recognized by the general principles of international law," anywhere on the high seas. ${ }^{28}$ There is an independent duty to exercise high seas freedoms with reasonable regard for the exercise of the freedom of the high seas by other states. ${ }^{29}$ To convert a duty of reasonable regard into a

${ }^{27}$ Id. Part II, Art. 48.

${ }^{28}$ Convention on the High Seas, Art. 2; 13 UST 2312, TIAS No. 5200, 450 UNTS 82, 52 AJIL 842 (1958); See RSNT, Part II, Art. 76.

$29 \mathrm{Id}$. 
limiting as well as expansive concept of a right to do anything reasonable is to substitute subjective judgment for law.

The high seas tradition is that exclusion or control of the activities of others is prohibited unless specifically permitted. The latter principle is stated categorically in the High Seas Convention and the RSNT. ${ }^{30}$ Starting with sailing ships and fishing, that tradition has welcomed countless new uses, including powered ships, submarines, aircraft, oceanographic ships, communications cables and pipelines, data collection devices, offshore ports, etc. It was considered inhospitable to offshore oil development, and accordingly a partition of continental shelf resources among coastal states ensued. It has recently come to be considered inhospitable to fishing and other interests of coastal states, resulting in a fishing or economic zone partition among coastal states.

The underlying question is whether the tradition is antagonistic to deep seabed mining, and if so, whether it is sufficiently antagonistic to necessitate some type of partition. The answer in the RSNT is affirmative, although in a very carefully limited way that is far more circumscribed in scope than the continental shelf partition and that in fact seeks to preserve the underlying concept of a universal right to use the area. ${ }^{31}$ Whether states should proceed with such a partition pending agreement on ground rules and limitations for partition is a basic policy question that faces them today.

\section{The ECONOMic ZoNe}

The economic zone is a radical experiment in international law. It has precursors. In conceptual terms, it can be seen as an outgrowth of the contiguous zone and the continental shelf. But in practical terms, it is a wholly new approach to solving the classic dilemma of choosing between mare clausum and mare liberum.

The essence of the economic zone is functional precision. It is best described by its constituent elements. No single concept dictates the conclusions reached with respect to different types of uses. Indeed, it is noteworthy that the dispute over the legal status of the economic zone is only now reaching its greatest intensity in the negotiations, after widespread agreement on many of the zone's main constituent elements has emerged.

The "radical" aspect of the economic zone is the attempt to apply modified mare clausum and mare liberum solutions to different problems in the same area. Unlike the contiguous zone, the economic zone is not a "buffer" where jurisdiction is linked to a violation of law in the territory or in the territorial sea of the coastal state..$^{32}$ Unlike the continental shelf doctrine, the economic zone concept applies in major ways

\footnotetext{
3" Convention on the High Seas, supra note 28, Arts. 6 \& 22; RSNT, Part II, Arts. 80,98 .

II RSNT, Part I, Arts. 3, 4, 7, 8.

32 See id., Part II, Art. 32; Convention on the Territorial Sea and the Contiguous Zone, Art. 24; 15 UST 1606, TIAS No. 5639, 516 UNTS 205, 52 AJIL 851 (1958).
} 
to uses of the water column..$^{33}$ Nevertheless, in establishing coastal state jurisdiction over resources, but preserving, for example, the freedom to lay and maintain submarine cables and pipelines and providing for accommodation of other freedoms in the water column by prohibiting unjustifiable interference with those freedoms, the 1958 Conventions did presage the economic zone. ${ }^{34}$

Under the RSNT, some activities can be conducted in the economic zone only with the consent of the coastal state. ${ }^{35}$ With respect to some of these, coastal state discretion to deny consent and regulate the activity is circumscribed. $^{36}$ Other activities can be conducted in the economic zone without coastal state consent. ${ }^{37}$ With respect to some of these, certain regulatory or enforcement powers are given the coastal state. ${ }^{38}$ Thus, different states will have jurisdiction over different activities in the same area; not infrequently, there will be concurrent jurisdiction, usually for different purposes.

Is such a complex arrangement stable? There is no way to tell now. Some proponents and some opponents of the economic zone concept originally saw in it the seeds of a transition to a territorial sea or its equivalent, although the majority of proponents and opponents seem to expect it to be a permanent arrangement. While one may quarrel with the results, certainly no more universal, and probably no more painstaking, review of relevant coastal and international interests with respect to each ocean use has ever been undertaken.

The totality of the economic zone regime is spread through Parts II, III, and IV of the RSNT. The main body, found in Part II, was not significantly changed from the original SNT; thus the comments made by the author in this respect in the earlier article ${ }^{39}$ need not be repeated here. More attention will be devoted to an analysis of the zone set forth in the RSNT as a juridical concept and model.

One basic characteristic of the economic zone is that it does not entail an unfettered discretion for any state. Two central duties qualify the rights and obligations of both coastal and flag states.

First, in exercising its rights and performing its duties in the zone, the coastal state must have due regard to the rights and duties of other states; ${ }^{40}$ in exercising their rights and performing their duties in the zone, other states must have due regard to the rights and duties of the coastal state.11 It can be anticipated that these balanced duties will provide the juridical

\footnotetext{
${ }^{33}$ See Convention on the Continental Shelf, supra note 23, Arts. 1, 3; RSNT, Part II, Arts. 44, 64, 66.

34 See Convention on the Continental Shelf, supra note 23, Arts. 2, 4, 5; Convention on the High Seas, supra note 28, Art. 2.

35 See, e.g., RSNT, Part II, Arts. 44, 48, 50, 51, 69; Part III, Art. 60.

36 See, e.g., id. Part II, Arts. 51, 53, 58, 59; Part III, Art. 60.

37 See, e.g., id. Part II, Arts. 46, 47, 77-103.

38 See, e.g., id. Part III, Arts. 20, 21, 26, 28, 30, 43.

30 Stevenson \& Oxman, supra note 2 , at 774-81.

40 RSNT, Part II, Art. 44(2).

41 Id. Part III, Art. 46(3).
} 
basis for resolving many practical problems of competing uses. The analogous high seas duty of a state exercising high seas freedoms to have reasonable regard for others exercising those freedoms is the antecedent of these rules, ${ }^{42}$ but curiously was not itself incorporated by reference into the economic zone. This was presumably an oversight, as the duty would apply, for example, as between two states exercising freedom of navigation in the zone.

Second, both coastal and flag states are subject to general environmental duties, as well as specific environmental duties with respect to specific uses. $^{43}$ In general, the environmental rights and duties rest with the state exercising jurisdiction over the source or potential source of pollution. ${ }^{44}$ In the case of ships, there are additional environmental rights and duties for port states and coastal states. ${ }^{* 5}$

While it can be argued that duties of this character also exist in general international law applicable to all activities of states, the RSNT represents a very significant advance in its attempt to enunciate these duties as positive law. To the extent that they are subject to third-party dispute settlement procedures, the potential for meaningful application of these duties, in a manner that takes into account differing circumstances, is greatly expanded.

It is customary, when discussing the economic zone, to list the relevant rights. Since these are inaccurately and somewhat incompletely summarized in the text itself, a new summary might be of some use. In brief, under the RSNT, the coastal state enjoys:

-sovereign rights for the purpose of exploring and exploiting, conserving, and managing the natural resources of the zone; ${ }^{46}$

-exclusive jurisdiction (including the exclusive right to construct and authorize and regulate the construction, operation, and use) with respect to (i) artificial islands, (ii) installations and structures for purposes otherwise subject to its jurisdiction (e.g., resources) and for other economic purposes, and (iii) installations and structures which may interfere with the exercise of the rights of the coastal state in the zone; and in addition the right to establish necessary safety zones of specified breadth around such artificial islands, installations, and structures; ${ }^{47}$

-exclusive jurisdiction with regard to other activities for the economic exploitation and exploration of the zone, such as the production of energy from the water, currents, and winds; ${ }^{48}$

-the exclusive right to authorize and regulate seabed drilling for all purposes; ${ }^{49}$

*2. Note 28, supra.

$\$ 4$ Id.

45 Id. Part II, Art. 44; see also Arts. 50-57, 64-65.

43 RSNT, Part III, Chapter $\mathrm{Y}$.

45 Id. Arts. 20, 21, 26, 28, 29, 30, 31 .

${ }^{47}$ Id. Part II, Art. 48; see also Art. 68.

4*Id. Part II, Art. 44. The words "exploitation and exploration of the zone" and "production" are of course designed to ensure that navigation is not covered by this rubric.

40 Id. Part II, Arts. 64, 69. 
- the right to be notified of, and to participate in, scientific research in the economic zone, including access to and assistance in interpreting all data and samples, and the right to consent to scientific research in the zone, provided that the coastal state "shall not withhold consent" unless the project bears substantially upon the exploration and exploitation of resources or meets other specified criteria; ${ }^{\text {so }}$

- the right to consent to the delineation of the course for laying thirdstate pipelines; ${ }^{51}$

-the right of hot pursuit in respect to its competence in the zone; ${ }^{\text {:2 }}$

-the right to establish and enforce antipollution regulations (no less effective than international rules and standards) with respect to seabed activities, artificial islands, installations, and structures under its jurisdiction, ${ }^{53}$ third-state pipelines on the seabed, ${ }^{54}$ and dumping of wastes and other matter in the zone; 55

-the right to designate special areas meeting certain criteria in which it may implement, in the absence of disapproval by the competent international organization, such antipollution rules and standards for foreign vessels as have been made applicable for special areas by the competent international organization (at present special discharge regulations); ${ }^{\text {to }}$

-the right to establish and enforce antipollution regulations for vessels in ice-covered areas meeting certain criteria; ${ }^{67}$

-the right to undertake physical inspection in case of vessel discharges in violation of international standards and, in more extreme cases, to bring proceedings against the vessels, subject to considerable safeguards, such as prompt release on payment of bond, and" "Hlag state preemption" of coastal state proceedings if flag states are effectively enforcing environmental regulations against their vessels, except where there is major damage to the coastal state; ${ }^{68}$

-the already established right of intervention, i.e., the right to take preventive measures in the event of grave and imminent danger from pollution or threat of pollution following upon a maritime casualty. ${ }^{60}$

(As might be expected, none of the pollution provisions apply for practical reasons to warships and other government noncommercial vessels and state aircraft.) ${ }^{60}$

At the same time, in the economic zone, under the RSNT all states enjoy "the freedoms of navigation and overllight and of the laying of sub-

5o Id. Part III, Arts. 58-60.

52 Id. Part II, Art. 99(2).

54 Id. Part II, Art. 67(2).

56 Id. Part III, Arts. 21(5), 30(3-6, 8).

Id Part III Arts 4(4), 5,

59 Id. Part III, Art. 31. See International Convention Relating to Intervention on the High Seas in Cases of Oil Pollution Casualties, 1969, TIAS No. 8068, 9 ILM 25 (1970); Protocol Relating to Intervention on the High Seas in Cases of Marine Pollution by Substances Other than Oil, 1973, 13 ILM 605 (1974).

60 RSNT, Part III, Art. 45.
51 Id. Part II, Art. 64, 67(3).

53 Id. Part III, Arts. 18, 24.

55 Id. Part III, Arts. 20, 26.

57 Id. Part III, Art. 43. 
marines cables and pipelines and other internationally lawful uses of the sea related to navigation and communication." 'st States also have the right to conduct marine scientific research, subject to the rights and duties of the coastal state set forth in the Convention. ${ }^{62}$ In addition, Articles 77 to 103 "and other pertinent rules of international law apply to the exclusive economic zone in so far as they are not incompatible with this Chapter" (on the economic zone). ${ }^{* 3}$ Articles 77 to 103 comprise all of the substantive nonfisheries provisions of the high seas chapter except for the definition of the high seas and the list of high seas freedoms; these provisions are subtantially the same as those in the High Seas Convention. ${ }^{64}$ However, the economic zone is excluded from the definition in Article 75 of the high seas. $^{\text {is }}$

The debate over the status of the economic zone, which necessarily involves these provisions, does not therefore relate in a strict legal sense to the preservation of navigational and other communications freedoms, or to the preservation of classic high seas law in the zone. The latter includes, for example, the nationality of ships, exclusive jurisdiction of the flag state over its ships except as otherwise specified (which would include classic high seas exceptions such as piracy, as well as new economic zone exceptions such as fisheries and pollution enforcement), immunity of warships and government noncommercial ships, the duty to render assistance, the suppression of piracy and slave trade, and hot pursuit.

In a strict juridical sense, the economic zone elaborated in the RSNT should be regarded as an overlay on the high seas. It generally eliminates freedom of fishing and to a certain degree some other freedoms (e.g., with respect to some scientific research and installations) and establishes a measure of concurrent rights or jurisdiction with respect to others (e.g., some scientific research and some vessel-source pollution), but it does not eliminate the traditional role of the flag state.

The clearest example of this is in the articles on vessel-source pollution. The rights of the coastal state do not displace the rights and duties of the flag state to control pollution from its vessels, but rather supplement them. ${ }^{68}$ However, other examples are worth noting as well. The sovereign rights of the coastal state with respect to fishing do not deprive a fishing vessel of freedom of navigation; nor do they deprive the flag state of its jurisdiction over that vessel, for example in the event of a collision, ${ }^{67}$ or even its right to punish the master and crew for violating coastal state fishing laws independent of any coastal state action. The existence of separate jurisdiction over the same vessel in the same area depending on its activities may require some nice accommodations in practice, depending on the facts.

61 Id. Part II, Art. 46(1).

62 Id. Part III, Art. 49.

i3 Id. Part II, Art. 46(2).

"4 Convention on the High Sea, note 28 supra.

i5 RSNT, Part II, Art. 75.

iti Id. Part II, Arts. 79, 80, 82, 85; Part III, Arts. 4, 21(2), 26(1)(b), 27, 28(2,3), $30(4,7), 38,40,44,45$.

เ7 Id. Part II, Art. 85. 
Absent specific evidence, it would be manifestly unjustifiable to stop and board a freighter or oil tanker navigating through the zone to ensure that it is not fishing, but it would also be manifestly imprudent to expect the coastal state to refrain from inquiry regarding a large fishing fleet moving slowly with gear in readiness and with no apparent destination through a rich fishing ground far from any known navigation ronte.

The debate on the status of the economic zone has also raised questions of priorities. The text as it stands does not assign priorities of use as between the coastal state and others as such. Resolution of the issue depends on the use, not on the state with jurisdiction. It is obvious that an installation necessarily enjoys priority of use in the area it occupies. This is why installations and their safety zones may not be placed where interference may be caused to recognized sealanes essential to international navigation, and why coastal states are given control over installations that may interfere with the exercise of their rights in the zone. ${ }^{08}$ The International Regulations for the Prevention of Collision at Sea (1960) in effect provide certain priorities for vessels engaged in fishing, and deal with other questions of "rules of the road." 69 Thus, it is the details of the Convention itself and classic high seas traditions and rules incorporated by reference, rather than the status of the zone, that govern the question.

A more interesting argument regarding the legal status of the economic zone relates to the question of "residual rights." The chairman of Committee II in his latest report specifically confirmed his view that "the matter should be addressed in terms of 'residual rights." 70 Article 47 of the Committee II text provides:

In cases where the present Convention does not attribute rights or jurisdiction to the coastal State or to other States within the exclusive economic zone, and a conflict arises between the interests of the coastal State and any other State or States, the conflict should be resolved on the basis of equity and in the light of all the relevant circumstances, taking into account the respective importance of the interests involved to the parties as well as to the international community as a whole.

What are these residual rights? Would the result be any different under Article 2 of the High Seas Convention, which refers to "others [freedoms] recognized by the general principles of international law," enumerating only four freedoms explicitly, three of which are expressly preserved in the economic zone, ${ }^{71}$ and one of which is expressly omitted and converted to a coastal state sovereign right? 72 Since the Conference is deadlocked on the status issue, one must presume that weighty considerations are involved, and not merely frivolous if fascinating questions such as swimming from a pleasure boat.

68 Id. Part II, Art. 48.

${ }^{69} 16$ UST 794. TLAS No. 5813.

${ }^{70}$ Note 5 supra, L.17, para. 26; RSNT, Part II, Introductory Note, para. 18.

71 Navigation, overflight, submarine cables, and pipelines. RSNT, Part II. Art. 46.

72 Fishing. Id. Part II, Art. 44. 
Let us review the catalog. All economic rights are expressly attributed in the text: there is no economic residuum. Rights regarding scientific research are expressly dealt with. All drilling into the seabed requires coastal state consent. While the absence of records is a decided handicap, it was well understood in the "Evensen Group" which originally drafted Article 46, paragraph 1, that freedom to enjoy "other internationally lawful uses of the sea related to navigation and communication" was in addition to full freedom of navigation and overflight, and the article is intentionally so drafted. It was also negotiated after completion of the relevant articles relating to economic rights of the coastal state, in conjunction with the article that gave the coastal state jurisdiction not only over economic installations, but other installations "which may interfere with the exercise" of coastal state rights in the zone; and in the face of proposals to include "all installations" within coastal state jurisdiction that were unequivocally rejected.

What then is left? When would a warship or military aircraft not be engaged in navigation, overflight, or activities related to navigation and overHlight? Readiness to defend sealanes and communications, including public manifestations of such readiness, has been a classic mission of navies for millennia. A use or threat of force brings the matter within the ambit of the UN Charter. The lawfulness of any other activity in principle does not relieve the flag state of its duty to have due regard to the rights and duties of the coastal state, which presumably covers such hypothetical concerns as damage to resources. More to the point, the warship is under the exclusive jurisdiction of the flag state in any event. It is relatively easy for a flag state to argue that any likely activities are covered by Article 46. It is also relatively easy to make out a good case for the flag state under the "respective importance to the parties" rule in Article 47. What precisely is it that the coastal state could or would do if the zone is not high seas that it would otherwise be unwilling or unable to do? Particularly since the elaboration of coastal state economic rights in the zone has now survived careful review by the Conference, the elimination of the words "related to navigation and communication" from Article 46 would better reflect the actual result and reduce the possibilities for misunderstanding.

The author's opinion is that the main problem with the text lies in the subjective impression given by the combination of Articles 46, 47, and 75 together, in that Article 75 in particular seems to contradict the intricate legal system that comprises the economic zone. The implication that high seas freedoms and high seas law are not preserved in the economic zone is contradicted by a close reading of the text, and even more importantly, by the basic assumptions surrounding the negotiation of the economic zone. Yet that implication could prove to be a temptation for coastal states to seek to alter the balance of the economic zone. A 200-mile territorial sea claimant might conveniently refuse to ratify the new "contract," yet point to the "decision in principle" that the area within 200 miles of the coast is not high seas. If supple, it might concede freedom of naviga- 
tion in principle but then impose restraints that would not be permissible were it a party to the "contract." The fact that current 200-mile territorial sea claimants are among the most vociferous opponents of high seas status for the economic zone cannot be overlooked.

Thus, the real issue is that posed at the outset of the discussion of the economic zone, namely "Is such a complex arrangement stable?" If it is not, why should maritime states make the concessions inherent in the RSNT? Why concede any jurisdiction regarding scientific research? Why make any concessions on high technology operations such as installations or production of energy from water, currents, and winds? Important coastal states can control them by regulating connections to their land territory without direct offshore jurisdiction. Why concede coastal state vessel-source pollution rights in the zone when the risks to navigation may outweigh any real environmental benefits? Why compromise at all on highly migratory species? The answer of course is that these issues would be contentious anyway, and that a stable settlement would be in the overall interests of all concerned. But that presumes a stable settlement, not a steppingstone to a territorial sea.

A balanced solution, one that will engender stability, would be to follow the approach of the 1958 Territorial Sea, Continental Shelf, and High Seas Conventions, which establish clear coastal state rights beyond the territorial sea while making it clear that areas beyond the territorial sea retain their status as high seas.

Given this uncertainty, it seems possible that only a fishing zone-rather than an economic zone as described in the RSNT-will be absorbed into generally recognized customary law in the near term, although some states will certainly claim a full economic zone. The content of the fishing zone is likely to resemble that described in the RSNT. It is possible that the RSNT definition of the continental shelf as embracing the deep seabed as well as continental margin areas within 200 miles will also be absorbed quickly, ${ }^{\text {T3 }}$ although the implications of extension of the continental shelf concept to the deep seabeds in principle and without precise agreement on limits bear some careful thought.

On the other hand, if the four main outstanding issues regarding the economic zone are resolved in the negotiations-the status of the zone, scientific research, access of landlocked and geographically disadvantaged states to fisheries, and dispute settlement-then the probability of a widely acceptable treaty dramatically increases (assuming a way around the Committee I problem). Whether the probability of a customary law economic zone along the lines of the RSNT also increases is unclear, since such a development would not be accompanied by the protection of dispute settlement. This is a particularly weighty consideration with respect to coastal state rights regarding vessel-source pollution. It is entirely possible that, at least in this regard, some states will view the existence of compulsory third-party settlement procedures as an essential substantive ele-

73 Id. Part II, Art. 64. 
ment of any concession of coastal state rights and may be reinforced in their disquietude by claims that assert comprehensive pollution control jurisdiction, rather than the refined rights in Part III of the RSNT, because of the imprecise drafting of Article 44 of Part II. In this case, it of course still remains open to amend a treaty like the 1973 London Convention ${ }^{i t}$ to incorporate the substantive and procedural provisions of the RSNT on pollution as a means of obtaining a complete package, but the question of incentives would remain.

Part IV of the new RSNT, on the settlement of disputes, ${ }^{75}$ once again illustrates the central importance of the dispute settlement issue to the overall balance of the economic zone. Compulsory procedures apply to disputes "relating to the exercise by a coastal State of sovereign rights, exclusive rights or exclusive jurisdiction . . . only" in the cases specified in Article $17, \%$ including violations regarding navigation and overflight, environmental and scientific research questions, and an interesting provision on living resources.

As in the earlier texts, a state still may declare the forum in which it is subject to suit and may choose one or more of the following: a new Law of the Sea Tribunal, the International Court of Justice, arbitration, or special arbitration procedures utilizing experts for fisheries, pollution, scientific research, or navigation disputes. ${ }^{77}$ However, the plaintiff may now not only initiate proceedings in the forum chosen by the defendant but also choose arbitration. ${ }^{\pi s}$

Of the relatively few changes made in Part II of the RSNT, one is of particular interest to states that are proceeding to establish 200 -mile zones at present. Articles 61 and 70 of the SNT had provided that the median or equidistant line should be provisionally applied between opposite or adjacent states pending settlement between them on delimitation of the economic zone and continental shelf. This rule has now been eliminated. A clause has been substituted to the effect that the states concerned should make provisional arrangements, "taking into account the provisions of paragraph $1,{ }^{\prime}$ " namely the general principles regarding delimitation. In his introductory note, the Chairman of Committee II explained: "Since the Conference may not adopt a compulsory jurisdictional procedure for the settlement of delimitation disputes, I felt that the reference to the median or equidistant line as an interim solution might not have the intended effect of encouraging agreements." so Part IV of the RSNT permits a state to

7* International Convention for the Prevention of Pollution from Ships, 1973, IMCO Doc. MP/ConF./WP.35, Nov. 2, 1973 (not yet in force), I2 ILM 1219 (1973).

is Note 6, supra. The provisions in the RSNT on dispute settlement are not discussed in detail here, since they are the subject of a note appearing elsewhere in this issue of the Journal. See Adede, Law of the Sea: The Scope of the Third-Party, Compulsory Procedures for Settlement of Disputes, infra, p. 305.

765 For text of Article 17, see infra p. 305.

i7 RSNT, Part IV, note 6, supra, Art. 9(1).

7. Id. Part IV, Art. 9(5).

79 Id. Part II, Arts. 62(3), 71(3).

nil Id. Part II, Introductory Note, para. 12. 
make a declaration excluding "disputes concerning sea boundary delimitations between adjacent or opposite States" from compulsory procedures under the Convention, "provided that the State making such a declaration shall indicate therein a regional or other third party procedure, entailing a binding decision, which it accepts for the settlement of such disputes." 81

While delimitation problems are not new, the urgency of the problem in connection with extensions of fisheries jurisdiction is of some importance. Unlike oil development, fishing has been conducted for centuries in many border areas under high seas principles. The number of people involved can be large; the basic investment has already been made; fishermen tend to be highly individualistic. Moreover, delimitation problems can accentuate disputes over islands and land boundaries. Even where the two coastal states can temporarily tolerate a status quo arrangement regarding their respective fishermen, the question of who deals with third states remains. What precisely will occur in areas where the coastal state governments in question are at best not on speaking terms? While a new source of friction is hardly welcome, in some cases the practical need for some arrangement may present an opportunity for dialogue.

\section{ConcLusion}

The Law of the Sea Conference has reached the stage where governments must weigh the benefits and losses of a treaty against no treaty. For most, positive as well as negative factors are involved. More importantly, the closer the treaty comes to reflecting a "realistic" balance of interests, the more it seems to approximate likely developments in the absence of a treaty, positive or negative. Rather than overtly accept the unpleasant aspects of those realities, some may prefer to let events develop, and possibly avoid or leave to others the responsibility for facing up to those realities.

The underlying perceptions of future reality without a treaty are probably all wrong in some respects; many may be gravely wrong in major respects. Many governments are seeing the issue through the eyes of those who have participated in or have been horrified by the Law of the Sea Conference, or both, and who are not responsible for actual operational problems. They tend to base their projections on statements, threats, and negotiating assumptions, not on projections of the actual stuff of customary law, namely the behavior of states (not merely their words) in difficult situations where competing interests are at stake. The author's view is that one result of no treaty may be a struggle over navigation and possibly some resources that will gradually become considerably more costly and unpleasant for many. But again, the cost is a future one, not a present one as with treaty "concessions."

Since the inception of the negotiations, three basic motive forces for a treaty have been: first, to protect navigation and overflight from coastal

81 Id. Part IV, Art. 18(1)(a). 
state incursions; second, to achieve broad coastal state control of living and nonliving resources and ancillary matters; and third, to establish an international regime for the seabeds beyond coastal state jurisdiction under an entirely new concept of the common heritage of mankind.

For the most part, as regards fisheries, the second motive force has been reduced by developments outside the Conference, ironically based upon its very success. The United States, ${ }^{82}$ the European Communities, ${ }^{83}$ and the Soviet Union ${ }^{4}$ have joined other coastal states ${ }^{85}$ in declaring a 200 -mile fisheries zone. Despite years of work on the issue, there is still doubt as to the extent to which the majority of states perceive the magnitude of their interests in navigation and overflight, or the danger that the generally satisfactory (and in some cases markedly improved) navigational regimes in the RSNT may be lost without a treaty. As to the third motive force, the realization that concepts of the common heritage must come to grips with real interests has had a deflating effect.

Thus, the basic purpose of this treaty-like any other institutional treaty designed to govern long-term relationships-is only now becoming apparent in more than a rhetorical sense. The ultimate value of the treaty lies not in any extraordinary substantive windfalls, but as with most treatiesindeed as with most law-in the relative increase in stability, certainty, predictability, and common principles and procedures for narrowing and resolving differences. The "political decisions" states must now make turn on the relative weight they collectively attach to these achievements. It is not so much the sea as it is international law and the development of cooperative international institutions that hang in the balance.

* Fisheries Conservation and Management Act, 90 Stat. 331, PL 94-265, 16 USC 1801, 70 AJIL 624 (1976), I5 ILM 634 ( 1976).

* Resolution of the Council of the European Communities on External Aspects of the Creation of a 200-mile Fishery Zone, 15 ILM 1425 (1976).

4 Decree of the Presidium of the Supreme Soviet of the U.S.S.R. Dec. 10, 1976, UN Doc. A/Conf. 62/53 (1977), 15 ILM 1381 (1976).

* E.g., Canada, Order-in-Council, 110 Can. Gaz. Part I, Extra No. 101, Nov. 1, 1976, 15 ILM 1372 (1976). Mexico, Decree Adding to Article 27 of the Political Constitution, Diario Official, Feb. 6, 1976, 15 ILM 380 (1976). 